\title{
MATERNAL AGE AND BIRTH RANK IN THE AETIOLOGY OF MONGOLISM
}

\author{
BY \\ ALWYN SMITH AND R. G. RECORD \\ From the Department of Social Medicine, University of Birmingham
}

The incidence of mongolism increases so remarkably with advancing maternal age that it hardly seemed necessary to earlier workers to know the maternal age structure of the population from which their cases were drawn (Shuttleworth, 1909; Brousseau, 1928; Engler, 1949), or to ensure that the control group was representative (Jenkins, 1933; Rosanoff and Handy, 1934; Lahdensuu, 1937; Bleyer, 1938; Benda and others, 1943; Beall and Stanton, 1945). These precautions were not neglected by Carter and MacCarthy (1951), who used a series of hospital births to establish firmly the relationship between incidence and maternal age.

Association with birth rank has been studied with less satisfactory results. Conflicting opinions have been expressed by investigators who did not have access to a satisfactory control group (Shuttleworth, 1909; Brousseau, 1928; Murphy, 1936; Bleyer, 1938; Beidleman, 1945), and the need first to eliminate the effect of maternal age has usually been overlooked. Examination of the separate effect of birth rank has rarely been attempted. Malzberg (1950) used the GreenwoodYule method to investigate the influence of birth rank at each maternal age group, but his results are misleading since many of the unaffected sibs were born outside the maternal age range under consideration. A more acceptable adaptation of the Greenwood-Yule method designed to remove the influence of maternal age was used by Penrose (1934), who found that the risk of mongolism in first-born was slightly raised although the result was not statistically significant. He recognized that the method may give false results if applied to incomplete sibships, and avoided this error by selecting cases some years after birth when most of the fraternities were probably complete. This manoeuvre may be equally misleading as a result of the high early mortality of mongols. In a previous communication (Record and Smith, 1955) it was noted that the usual cause of death is infectious disease. In view of the marked increase in infant mortality from infection with birth order (Gibson and McKeown, 1952), it would be expected that a series collected some years after birth would show a deficiency in the later birth ranks. Mortality is greater for female than for male mongols, and the increase in the proportion of males with increasing birth rank exhibited by Penrose's series is consistent with this interpretation. The demonstration by Øster (1953) of an excess of mongols at the lower birth ranks, compared with normal infants born to mothers of the same age, may have a similar explanation since his observations were confined to mongols alive at the time of the inquiry.

It appears therefore that the question whether birth order is of aetiological importance in mongolism has not been satisfactorily answered. In an attempt to explore this problem we have collected data on a substantial series of mongols most of which were ascertained soon after birth, and on a control group representative of the population of births from which the affected subjects were drawn.

\section{MATERIAL}

An attempt was made to obtain information about all mongols born during the years 1942 to 1952 to mothers normally resident in the city of Birmingham. Sources of ascertainment have been described previously (Record and Smith, 1955). 252 cases were recorded, of which 217 were traced and the mothers interviewed in their homes. Of the remainder, three mothers refused to co-operate, and 32 either had left the city or had removed and were not traced.

A control series of 1,156 births, representative of the population of births from which the affected subjects were drawn, was obtained by taking every 200th entry from the birth notification records of the Maternity and Child Welfare Department. Controls had previously been assembled for the years 1942 to 1949 (McKeown, 
MacMahon, and Record, 1951); the series was completed by the addition of births for the years 1950 to 1952 .

The maternal age of the controls was given in birth notification records; birth rank (estimated from the number of previous live births and stillbirths, abortions being excluded) was derived from the same source. The maternal age at birth of the mongols was obtained in 217 cases at interview, and was available from the source of ascertainment in a further 24. The birth rank of the mongols was accepted only for the cases interviewed, since it was noted that the interpretation of the term in the recorded material was inconsistent, and that the information about stillbirths was sometimes incomplete. Maternal age was satisfactorily recorded in respect of 241 of the original 252 affected, and birth rank in respect of 217.

\section{RESULTS}

Table I gives distributions of 241 mongols and 1,156 controls according to maternal age at birth. The incidence of mongolism in each maternal age group has been estimated by using the age distribution of controls to calculate the age distribution of the population of births from which the affected were drawn. It shows the usual well-marked increase as maternal age increases.

TABLE I

INCIDENCE ACCORDING TO MATERNAL AGE

\begin{tabular}{c|c|c|c}
\hline $\begin{array}{c}\text { Maternal } \\
\text { Age } \\
\text { (yrs) }\end{array}$ & $\begin{array}{c}\text { Number of } \\
\text { Mongols }\end{array}$ & $\begin{array}{c}\text { Number of } \\
\text { Controls }\end{array}$ & $\begin{array}{c}\text { Incidence of Mongols } \\
\text { (per 1,000 related births) }\end{array}$ \\
\hline $15-19$ & 3 & 49 & $0 \cdot 31$ \\
$20-24$ & 17 & 278 & $0 \cdot 31$ \\
$25-29$ & 37 & 355 & $0 \cdot 52$ \\
$30-34$ & 44 & 273 & $0 \cdot 80$ \\
$35-39$ & 65 & 151 & $2 \cdot 15$ \\
$40-44$ & 67 & 46 & $7 \cdot 27$ \\
$45-49$ & 8 & 4 & $9 \cdot 99$ \\
\hline Total & 241 & 1,156 & $1 \cdot 04$ \\
\hline
\end{tabular}

Similar observations are given for each birth rank in Table II. As would be expected, the incidence of mongolism also increases with birth rank.

TABLE II

INCIDENCE ACCORDING TO BIRTH RANK

\begin{tabular}{l|c|c|c}
\hline $\begin{array}{c}\text { Birth } \\
\text { Rank }\end{array}$ & $\begin{array}{c}\text { Number of } \\
\text { Mongols }\end{array}$ & $\begin{array}{c}\text { Number of } \\
\text { Controls }\end{array}$ & $\begin{array}{c}\text { Incidence of Mongols } \\
\text { (per 1,000 related births) }\end{array}$ \\
\hline 1 & 61 & 397 & 0.77 \\
2 & 50 & 376 & 0.67 \\
3 & 34 & 174 & 0.98 \\
4 & 98 & 1.32 \\
5 and over & 46 & 111 & 2.07 \\
\hline Total .. & 217 & 1,156 & 0.94 \\
\hline
\end{tabular}

The effects of maternal age and birth rank are separated by examining the distributions of mongols and controls according to maternal age at each birth
TABLE III

DISTRIBUTIONS BY MATERNAL AGE AT EACH BIRTH RANK

\begin{tabular}{|c|c|c|c|c|c|}
\hline \multirow{2}{*}{$\begin{array}{l}\text { Birth } \\
\text { Rank }\end{array}$} & \multirow{2}{*}{$\underset{\text { (yrs) }}{\text { Maternal Age }}$} & \multicolumn{2}{|c|}{ Mongols } & \multicolumn{2}{|c|}{ Controls } \\
\hline & & Number & Per cent. & Number & Per cent. \\
\hline \multirow[t]{2}{*}{1} & $\begin{array}{c}15-19 \\
20-24 \\
25-29 \\
30-34 \\
35-39 \\
40 \text { and over }\end{array}$ & $\begin{array}{r}2 \\
9 \\
17 \\
16 \\
12 \\
5\end{array}$ & $\begin{array}{r}3 \cdot 3 \\
14 \cdot 8 \\
27 \cdot 9 \\
26 \cdot 2 \\
19 \cdot 7 \\
8 \cdot 2\end{array}$ & $\begin{array}{r}40 \\
160 \\
126 \\
46 \\
20 \\
5\end{array}$ & $\begin{array}{r}10 \cdot 1 \\
40 \cdot 3 \\
31 \cdot 7 \\
11 \cdot 6 \\
5 \cdot 0 \\
1 \cdot 3\end{array}$ \\
\hline & Total & 61 & 100 & 397 & 100 \\
\hline \multirow[t]{2}{*}{2} & $\begin{array}{c}15-19 \\
20-24 \\
25-29 \\
30-34 \\
35-39 \\
40 \text { and over }\end{array}$ & $\begin{array}{r}-3 \\
8 \\
12 \\
16 \\
11\end{array}$ & $\begin{array}{r}\overline{6 \cdot 0} \\
16 \cdot 0 \\
24 \cdot 0 \\
32 \cdot 0 \\
22 \cdot 0\end{array}$ & $\begin{array}{r}8 \\
91 \\
133 \\
93 \\
44 \\
7\end{array}$ & $\begin{array}{r}2 \cdot 1 \\
24 \cdot 2 \\
35 \cdot 4 \\
24 \cdot 7 \\
11 \cdot 7 \\
1 \cdot 9\end{array}$ \\
\hline & Total & 50 & 100 & 376 & 100 \\
\hline \multirow[t]{2}{*}{3} & $\begin{array}{c}15-19 \\
20-24 \\
25-29 \\
30-34 \\
35-39 \\
40 \text { and over }\end{array}$ & $\begin{array}{r}- \\
7 \\
4 \\
9 \\
14\end{array}$ & $\begin{array}{l}\overline{-} \\
20 \cdot 6 \\
11 \cdot 8 \\
26 \cdot 5 \\
41 \cdot 2\end{array}$ & $\begin{array}{r}1 \\
25 \\
54 \\
66 \\
21 \\
7\end{array}$ & $\begin{array}{r}0.6 \\
14 \cdot 4 \\
31 \cdot 0 \\
37.9 \\
12 \cdot 1 \\
4 \cdot 0\end{array}$ \\
\hline & Total $\ldots$ & 34 & 100 & 174 & 100 \\
\hline \multirow[t]{2}{*}{4} & $\begin{array}{c}20-24 \\
25-29 \\
30-34 \\
35-39 \\
40 \text { and over }\end{array}$ & $\begin{array}{l}- \\
3 \\
7 \\
8 \\
8\end{array}$ & $\begin{array}{l}\overline{11 \cdot 5} \\
26 \cdot 9 \\
30 \cdot 8 \\
30 \cdot 8\end{array}$ & $\begin{array}{r}2 \\
29 \\
33 \\
27 \\
7\end{array}$ & $\begin{array}{r}2 \cdot 0 \\
29 \cdot 6 \\
33 \cdot 7 \\
27 \cdot 6 \\
7 \cdot 1\end{array}$ \\
\hline & Total & 26 & 100 & 98 & 100 \\
\hline \multirow[t]{2}{*}{$\begin{array}{l}5 \text { and } \\
\text { over }\end{array}$} & $\begin{array}{c}25-29 \\
30-34 \\
35-39 \\
40 \text { and over }\end{array}$ & $\begin{array}{r}1 \\
1 \\
14 \\
30\end{array}$ & $\begin{array}{r}2 \cdot 2 \\
2 \cdot 2 \\
30 \cdot 4 \\
65 \cdot 2\end{array}$ & $\begin{array}{l}13 \\
35 \\
39 \\
24\end{array}$ & $\begin{array}{l}11.7 \\
31.5 \\
35.1 \\
21.6\end{array}$ \\
\hline & Total & 46 & 100 & 111 & 100 \\
\hline All Ran & All Ages .. & 217 & & 1,156 & \\
\hline
\end{tabular}

rank (Table III) and according to birth rank at each maternal age group (Table IV). The results leave little doubt that association with maternal age is almost independent of birth rank, and that association with birth rank is largely eliminated when the influence of maternal age is removed. There is, however, an excess of mongols in the first birth rank at all maternal ages except " 40 and over".

These points are considered in Tables $\mathrm{V}$ and VI (opposite). Table $\mathrm{V}$ shows the expected numbers of mongols at each age group estimated by a process of standardization designed to eliminate the effect of differences in birth rank distribution between mongols and controls. A significance test confirms the impression obtained from Table III, that the association between incidence and maternal age cannot be explained by differences in birth rank. Using a similar method to eliminate the effect of maternal age, it is shown (Table -VI) that the association with birth rank is much less marked, but that in the first birth rank there is a significant excess of mongols. 
TABLE IV

DISTRIBUTIONS BY BIRTH RANK AT EACH MATERNAL AGE

\begin{tabular}{|c|c|c|c|c|c|}
\hline \multirow{2}{*}{$\begin{array}{l}\text { Maternal } \\
\text { Age (yrs) }\end{array}$} & \multirow{2}{*}{$\begin{array}{l}\text { Birth } \\
\text { Rank }\end{array}$} & \multicolumn{2}{|c|}{ Mongols } & \multicolumn{2}{|c|}{ Controls } \\
\hline & & Number & Per cent. & Number & Per cent. \\
\hline \multirow[t]{2}{*}{$15-19$} & $\begin{array}{r}1 \\
2 \\
\quad \quad 3\end{array}$ & $\frac{2}{-}$ & $\begin{array}{c}100 \cdot 0 \\
二\end{array}$ & $\begin{array}{r}40 \\
8 \\
1\end{array}$ & $\begin{array}{r}81 \cdot 6 \\
16 \cdot 3 \\
2 \cdot 0\end{array}$ \\
\hline & Total .. & 2 & 100 & 49 & 100 \\
\hline \multirow[t]{2}{*}{$20-24$} & $\begin{array}{l}1 \\
2 \\
3 \\
4\end{array}$ & $\begin{array}{l}9 \\
3 \\
-\end{array}$ & $\begin{array}{c}75 \cdot 0 \\
25 \cdot 0 \\
- \\
-\end{array}$ & $\begin{array}{r}160 \\
91 \\
25 \\
2\end{array}$ & $\begin{array}{r}57.6 \\
32.7 \\
9.0 \\
0.7\end{array}$ \\
\hline & Total $\ldots$ & 12 & 100 & 278 & 100 \\
\hline \multirow[t]{2}{*}{$25-29$} & $\begin{array}{c}1 \\
2 \\
3 \\
4 \\
5 \text { and over }\end{array}$ & $\begin{array}{r}17 \\
8 \\
7 \\
3 \\
1\end{array}$ & $\begin{array}{r}47 \cdot 2 \\
22 \cdot 2 \\
19 \cdot 4 \\
8 \cdot 3 \\
2 \cdot 8\end{array}$ & $\begin{array}{r}126 \\
133 \\
54 \\
29 \\
13\end{array}$ & $\begin{array}{r}35 \cdot 5 \\
37 \cdot 5 \\
15 \cdot 2 \\
8 \cdot 2 \\
3 \cdot 7\end{array}$ \\
\hline & Total $\ldots$ & 36 & 100 & 355 & 100 \\
\hline \multirow[t]{2}{*}{$30-34$} & $\begin{array}{c}1 \\
2 \\
3 \\
4 \\
5 \text { and over }\end{array}$ & $\begin{array}{r}16 \\
12 \\
4 \\
7 \\
1\end{array}$ & $\begin{array}{r}40 \cdot 0 \\
30 \cdot 0 \\
10 \cdot 0 \\
17 \cdot 5 \\
2 \cdot 5\end{array}$ & $\begin{array}{l}46 \\
93 \\
66 \\
33 \\
35\end{array}$ & $\begin{array}{l}16 \cdot 8 \\
34 \cdot 1 \\
24 \cdot 2 \\
12 \cdot 1 \\
12 \cdot 8\end{array}$ \\
\hline & Total .. & 40 & 100 & 273 & 100 \\
\hline \multirow[t]{2}{*}{$35-39$} & $\begin{array}{c}1 \\
2 \\
3 \\
4 \\
5 \text { and over }\end{array}$ & $\begin{array}{r}12 \\
16 \\
9 \\
8 \\
14\end{array}$ & $\begin{array}{l}20 \cdot 3 \\
27 \cdot 1 \\
15 \cdot 3 \\
13 \cdot 6 \\
23 \cdot 9\end{array}$ & $\begin{array}{l}20 \\
44 \\
21 \\
27 \\
39\end{array}$ & $\begin{array}{l}13 \cdot 2 \\
29 \cdot 1 \\
13 \cdot 9 \\
17 \cdot 9 \\
25 \cdot 8\end{array}$ \\
\hline & Total .. & 59 & 100 & 151 & 100 \\
\hline \multirow[t]{2}{*}{$\begin{array}{l}40 \text { and } \\
\text { over }\end{array}$} & $\begin{array}{c}1 \\
2 \\
3 \\
4 \\
5 \text { and over }\end{array}$ & $\begin{array}{r}5 \\
11 \\
14 \\
8 \\
30\end{array}$ & $\begin{array}{r}7 \cdot 4 \\
16 \cdot 2 \\
20 \cdot 6 \\
11.8 \\
44 \cdot 1\end{array}$ & $\begin{array}{r}5 \\
7 \\
7 \\
7 \\
24\end{array}$ & $\begin{array}{l}10.0 \\
14.0 \\
14.0 \\
14.0 \\
48.0\end{array}$ \\
\hline & Total .. & 68 & 100 & 50 & 100 \\
\hline \multicolumn{2}{|c|}{ All Ages, All Ranks .. } & \multicolumn{2}{|l|}{217} & \multicolumn{2}{|l|}{1,156} \\
\hline
\end{tabular}

TABLE V

OBSERVED AND EXPECTED DISTRIBUTIONS OF MONGOLS ACCORDING TO MATERNAL AGE

\begin{tabular}{c|c|c|c}
\hline $\begin{array}{c}\text { Maternal Age } \\
(\text { yrs })\end{array}$ & $\begin{array}{c}\text { Number } \\
\text { Observed } \\
(a)\end{array}$ & $\begin{array}{c}\text { Number } \\
\text { Expected } \\
(b)\end{array}$ & $\begin{array}{c}\text { Difference } \\
(b)-(a)\end{array}$ \\
\hline $15-19$ & $20-19$ & 7.4 & +5.4 \\
$25-24$ & 12 & 42.1 & +30.1 \\
$25-29$ & 36 & 60.7 & +24.7 \\
$35-34$ & 40 & 55.6 & \pm 15.6 \\
$35-39$ & 59 & 36.3 & \pm 22.7 \\
40 and over & 68 & 14.9 & -53.1 \\
\hline Total.. & 217 & 217 & - \\
\hline
\end{tabular}

$x^{2}=149.6 ; n=5 ; p<0.0001$

- For method of calculating expected values see text.

We now inquire whether the effect of primogeniture may be accounted for by defects in the data. Three possible sources of error may be considered:

(1) The representation of first-born in the control group may be deficient. This possibility was examined
TABLE VI

OBSER VED AND EXPECTED DISTRIBUTIONS OF MONGOLS ACCORDING TO BIRTH RANK

\begin{tabular}{c|c|c|c}
\hline Birth Rank & $\begin{array}{c}\text { Number } \\
\text { Observed } \\
(a)\end{array}$ & $\begin{array}{c}\text { Number } \\
\text { Expected } \\
(b)\end{array}$ & $\begin{array}{c}\text { Difference } \\
(b)-(a)\end{array}$ \\
\hline 1 & 61 & $42 \cdot 7$ & $-18 \cdot 3$ \\
2 & 50 & $58 \cdot 1$ & $+8 \cdot 1$ \\
3 & 34 & $34 \cdot 0$ & 0.0 \\
4 & 26 & $27 \cdot 9$ & +1.9 \\
5 and over & 46 & $54 \cdot 3$ & $+8 \cdot 3$ \\
\hline Total $\quad$. & 217 & 217 & - \\
\hline
\end{tabular}

Comparing Birth Rank 1 with 2 and over: $\chi^{2}=7.91 ; n=1 ; p=0.005$.

in a previous communication (McKeown, MacMahon, and Record, 1951) and reasons were given for believing that the control group then available (for 1942-49) was representative of Birmingham births although it showed a lower proportion of first-born than the Midland I Region. Comparison between the control group used in the present study (1942-52) with the RegistrarGeneral's estimate for the Midland region for the period 1942-51 (the relevant statistics for 1952 are not published) again shows a deficiency of first-born in the control group. Part of the difference is due to our recognition of previous stillbirths as well as live births in calculating birth rank, whereas the Registrar-General restricts attention to previous live-born children. If the birth rank of mongols is adjusted by ignoring previous stillbirths, comparison with the Midland region by the method used in Table VI still shows a primogeniture effect (for one degree of freedom, $\chi^{2}=3.85 ; p=0.05$ ).

(2) The birth rank distribution of the 217 traced cases may differ from that of the 252 mongols identified. The effect of incomplete tracing was investigated in an earlier inquiry (Record and McKeown, 1949), in which it was shown that the proportion of first-born was less for interviewed cases than for those not found. Any error from this source would reduce rather than give rise to a primogeniture effect.

(3) The methods used in assembling the mongol series may favour identification of first-born. The observation that ascertainment of cases was more complete for hospital births than for domiciliary births (Record and Smith, 1955) combined with the fact that hospital deliveries are weighted in favour of primiparae gives some support for this possibility. That it is not the explanation for the primogeniture effect is readily shown by dividing mongols and controls according to place of birth and repeating the analysis (Table VII, overleaf). The excess of cases in the first birth rank is marked for subjects born in hospital, but much less so for those born at home.

An explanation of this difference according to place of birth may be found in the influence of birth rank on mortality (Table VIII, overleaf). Numbers are small, but the figures suggest that mortality rates for firstborn in the age period 14 days to 1 year are not influenced by place of birth; before the age of 14 days however, mongols born in hospital show a considerable mortality, but no deaths were recorded among the 
TABLE VII

OBSERVED AND EXPECTED DISTRIBUTIONS OF MONGOLS ACCORDING TO BIRTH RANK AND PLACE OF BIRTH

\begin{tabular}{|c|c|c|c|c|c|c|}
\hline \multirow{2}{*}{$\frac{\text { Place of Birth }}{\text { Birth Rank }}$} & \multirow[t]{2}{*}{. } & \multirow{2}{*}{$\cdots$} & \multicolumn{2}{|c|}{ Hospital } & \multicolumn{2}{|c|}{$\begin{array}{c}\text { Home and } \\
\text { Nursing Home }\end{array}$} \\
\hline & & & 1 & $\begin{array}{l}2 \text { and } \\
\text { over }\end{array}$ & 1 & $\begin{array}{l}2 \text { and } \\
\text { over }\end{array}$ \\
\hline \multicolumn{2}{|c|}{$\begin{array}{l}\text { Expected Number }(a) \\
\text { Observed Number }(b)\end{array}$} & $\begin{array}{l}\ldots \\
\cdots\end{array}$ & $\begin{array}{l}45 \\
31 \cdot 9\end{array}$ & $\begin{array}{l}56 \\
69 \cdot 1\end{array}$ & 16 & $\begin{array}{l}100 \\
102 \cdot 0\end{array}$ \\
\hline \multicolumn{2}{|c|}{ Difference $(b)-(a)$} & $\ldots$ & $-13 \cdot 1$ & $+13 \cdot 1$ & $-2 \cdot 0$ & $+2 \cdot 0$ \\
\hline$\overline{\chi^{2}(n=1)} \ldots$ & . & . & \multicolumn{2}{|c|}{$\begin{array}{c}6 \cdot 33 \\
p=0.01\end{array}$} & \multicolumn{2}{|c|}{$p=0.27$} \\
\hline
\end{tabular}

TABLE VIII

MORTALITY RATES (PER CENT.) OF MONGOLS

\begin{tabular}{|c|c|c|c|}
\hline \multirow{2}{*}{$\begin{array}{l}\text { Birth } \\
\text { Rank }\end{array}$} & \multirow{2}{*}{$\begin{array}{l}\text { Place } \\
\text { of } \\
\text { Birth }\end{array}$} & \multicolumn{2}{|c|}{ Age at Death } \\
\hline & & Under 14 days & 14 days to 1 year \\
\hline 1 & $\begin{array}{l}\text { Hospi- } \\
\text { tal .. } \\
\text { Home }\end{array}$ & $\left.\begin{array}{rr}28.9 & (45) \\
0.0 & (16)\end{array}\right\} 21 \cdot 3 \quad(61)$ & $\left.\begin{array}{cc}25 \cdot 0 & (32) \\
25 \cdot 0 & (16)\end{array}\right\} 25 \cdot 0 \quad(48)$ \\
\hline $\begin{array}{l}2 \\
\text { and } \\
\text { over }\end{array}$ & $\begin{array}{l}\text { Hospi- } \\
\text { tal .. } \\
\text { Home }\end{array}$ & $\left.\begin{array}{l}10 \cdot 7(56) \\
12 \cdot 0(100)\end{array}\right\} 11 \cdot 5(156)$ & $\left.\begin{array}{ll}26 \cdot 0 & (50) \\
35 \cdot 2 & (88)\end{array}\right\} 31 \cdot 9$ (138) \\
\hline
\end{tabular}

Numbers at risk are given in brackets

sixteen born at home. Almost certainly this group should also contain some subjects which died soon after birth and were not identified. We conclude that firstborn mongols are inadequately represented in the domiciliary group because mortality is high immediately after birth, and they die unrecognized. The hospital series, therefore, gives a more acceptable estimate of the effect of birth rank. It is concluded that, although the estimate given in Table VI may not be accurate, the finding that primogeniture is significant in the aetiology of mongolism may nevertheless be accepted.

A further point of interest shown in Table VIII is that the relationship between mortality and birth rank is reversed after the first fortnight of life. This is, of course, consistent with the view that mongols often die from infections, of which the risk increases with birth rank. It is probable that the same relationship is maintained throughout childhood, and it may more than offset the relatively disadvantageous position of first-born mongols at birth and for a short time afterwards.

\section{- Discussion}

The aetiological importance of maternal age in mongolism is so marked that it may be demonstrated by crude methods. The influence of primogeniture is much less obvious, and can probably be established only in series identified at birth. It is unlikely to be exhibited in cases diagnosed in the later months of the first year, and ascertainment in later childhood may lead to a spurious result because first-born infants are less exposed to infection and, if they survive the neonatal period, are less likely to die $\stackrel{\overparen{D}}{<}$ than later born. It seems probable that the small $\mathcal{O}$ primogeniture effect noted by Penrose (1934) can be explained in this way. By ascertaining cases at or shortly after birth it is possible to eliminate this. source of error.

The present investigation differs from that of Penrose in another respect. His technique was based on the Greenwood-Yule method, which $\frac{\bar{\sigma}}{\bar{\sigma}}$ depends on a comparison between affected and $\frac{\tilde{}}{\widetilde{\alpha}}$ unaffected members of the same sibship. Penrose $\triangle$ (1954) has pointed out that this method may give क a false result if the birth of an affected child deters $\overrightarrow{0}$ the parents from further reproduction. Although there is little evidence to support it, Southwick $\vec{\omega}$ (1939) considered this possibility to be likely in $\frac{\sigma}{\widehat{D}}$ families containing a mongol. In any case, the $\stackrel{\odot}{\frac{\AA}{9}}$ difficulty does not arise if a control group representa- 6 tive of all births is used. This method, however, has been criticized by Penrose (1954) on the grounds that $\stackrel{\text { ir }}{-}$ "errors could be introduced if mothers of affected 0

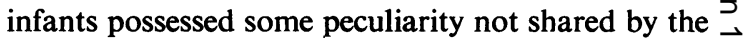
control mothers. For example, they might be $c$ disposed by constitution to produce children at $\stackrel{2}{2}$ relatively late ages".

In our view this possibility enhances rather than detracts from the value of the control group method $\vec{\theta}$ The discovery of a birth rank or maternal age effect of serves little purpose unless it is followed by a exploration of its possible causes. The investigation of fertility is an obvious first step; for this purpose the use of a properly constituted control group is essential.

We consider that, although the use of the Greenwood-Yule method is attractive in that it avoids the labour of assembling a series of controls, it is less informative and more open to error than the alternative method. The control group method has the further advantage that it makes possible an examination of the fertility of the mothers of affected children. It is proposed to deal with this aspect of the problem in a subsequent communication.

\section{SUMMARY}

(1) The association between the incidence of mongolism and maternal age and birth rank is of examined by comparing a series of 217 mongols $N$ born in Birmingham in the years 1942-52 with $N$ 1,156 infants representative of all births in the city $\frac{\omega}{\sigma}$ in the same period.

(2) The well-known relationship between incidence $\stackrel{\circ}{\simeq}$ and maternal age is shown to be little affected by eliminating the influence of birth rank. 
(3) Incidence increases regularly with increasing birth rank. When maternal age is fixed this association is eliminated, and incidence is greater in firstborn than in later born infants at all maternal ages except " 40 and over".

\section{REFERENCES}

Beall, G., and Stanton, R. G. (1945). Canad. J. publ. Hlth, 36, 33. Beidleman, B. (1945). Amer. J. ment. Defic., 50, 35.

Benda, C. E., Dayton, N. A., and Prouty, R. A. (1943). Amer. J. Psychiat., 99, 822.

Bleyer, A. (1938). Amer. J. Dis. Child., 55, 79.

Brousseau, K. (1928). "Mongolism". Bailliére, Tindall and Cox, London.

Carter, C., and MacCarthy, D. (1951). British Journal of Social Medicine, 5, 83.
Engler, M. (1949). “Mongolism (Peristatic Amentia)." Wright,

Gristol. Medicine, 6, 183 .

Jenkins, R. L. (1933). Amer. J. Dis. Child., 45, 506.

Lahdensuu, S. (1937). Acta paediat. (Stockh.), 21, 256.

McKeown, T., MacMahon, B., and Record, R. G. (1951). Ann. Eugen. (Lond.), 16, 249.

Malzberg, B. (1950). Amer. J. ment. Defic., 54, 266.

Murphy, M. (1936). Hum. Biol., 8, 256.

Oster, J. (1953). "Mongolism. A Clinico-genealogical Investigation comprising 526 Mongols living on Seeland and Neighbouring Islands of Denmark." Danish Science Press, Copenhagen.

Penrose, L. S. (1934). Ann. Eugen. (Camb.), 6, 108.

- (1954). Ann. N. Y. Acad. Sci., 57, 494.

Record, R. G., and McKeown, T. (1949). British Journal of Social Medicine, 3, 183.

and Smith, A. (1955). British Journal of Preventive and Social Medicine, 9, 10.

Rosanoff, A. J., and Handy, L. M. (1934). Amer. J. Dis. Child., 48, 764. Shuttleworth, G. E. (1909). Brit. med. J., 2, 661 .

Southwick, W. E. (1939). Amer. J. Dis. Child., 57, 68. 